\title{
Contrasting ability of deep and shallow rooting rice genotypes to grow through plough pans containing simulated biopores and cracks
}

\author{
Md. Dhin Islam (D) Adam H. Price • \\ Paul D. Hallett
}

Received: 3 June 2021 / Accepted: 14 August 2021 / Published online: 21 August 2021

(C) The Author(s) 2021

\begin{abstract}
Aims Cracks and biopores in compacted soil such as plough pans could aid deep rooting, mitigating constraints to seasonal upland use of paddy fields for rice production. This research investigated how soil macropores through a simulated plough pan affects root growth of contrasting deep and shallow rooting rice genotypes.

Methods Deep rooting Black Gora and shallow rooting IR64 rice varieties were grown in packed cores of unsaturated soil in a controlled greenhouse. Simulated biopores and cracks (macropores) were inserted through the plough pan to form treatments with no macropores, biopores, cracks, and combined cracks and biopores. Different root parameters such as root length density (RLD), root volume, root diameter,
\end{abstract}

Responsible Editor: Al Imran Malik.

M. Islam $(\varangle) \cdot$ A. H. Price · P. D. Hallett

Room 1.17, Cruickshank Building, School of Biological

Sciences, University of Aberdeen, St Machar Dr,

Aberdeen AB24 3UU, UK

e-mail: dhinislam@bsmrau.edu.bd

A. H. Price

e-mail: a.price@abdn.ac.uk

P. D. Hallett

e-mail: paul.hallett@abdn.ac.uk

M. Islam

Faculty of Agriculture, Bangabandhu Sheikh Mujibur

Rahman Agricultural University, Gazipur 1706,

Bangladesh number of root tips and branches were measured. The number of roots was calculated manually, including the number of roots growing through macropores in the plough pan layer.

Results Plough pans with macropores had 25-32\% more roots than with no macropores. RLD was $55 \%$ greater in the plough pan layer if cracks were present compared to biopores. Conversely, RLD was $26 \%$ less in subsoil if the plough pan had cracks compared to biopores. Different root parameters were greatly influenced by the presence of macropores in the plough pan, and deep-rooted Black Gora produced $81 \%$ greater RLD, $30 \%$ more root numbers and $103 \%$ more branching than the shallow rooted rice genotype IR64 within the plough pan layer.

Conclusions Macropores greatly improve rice root growth through plough pans for a deep rooting but not shallow rooting rice variety. Whereas cracks produce a greater number of roots in the plough pan, biopores result in greater root branching and root numbers deeper in subsoil.

Keyword Rice - Biopores - Cracks · Plough pan · Genotype $\cdot$ Macropores

\section{Introduction}

Rice is one of the main food crops in the world and around $90 \%$ of rice is produced and consumed in Asia (Coats 2003). Most rice is produced under 
flooded paddy systems where standing water is maintained from transplanting to harvesting (Bouman et al. 2007). However, the sustainability of flooded rice production is threatened by fresh water scarcity, labour shortages, and higher irrigation cost that affect the farmer (Bouman and Tuong 2001; Godfray et al. 2010). These impacts are exacerbated by climate change, with methane emission from flooded paddy systems thought to contribute $12 \%$ of the global emissions of this greenhouse gas. A conversion from continuously flooded rice paddy systems to either upland rice that is continuously drained or to alternate wetting and drying (AWD) irrigation offers solutions to help tackle water scarcity and decrease methane emissions. These new approaches can produce more rice with less water and more efficient fertiliser capture (Bouman 2001). Moreover, many regions grow multiple rice crops over the year, with growing conditions alternating between flooded and upland systems (e. g. Aus, Aman and Boro seasons in Bangladesh).

Regardless of the rice production system, longterm puddling in paddy systems, or tillage in upland systems, often produces a hard layer below the plough layer termed the plough pan (Li 1992). As rice farming becomes increasingly mechanised, heavy machinery may worsen the impact of plough pans on soil-water-plant relationships and plant root growth (Hamza et al. 2011). Singh et al. (2017) found a plough pan in more than half of 18 different rice growing study sites in Bangladesh, India and Nepal, with the existence of a plough pan varying from location to location. Plough pans inhibit deep root growth by affecting bulk density, porosity and penetration resistance of soil (Ishaq et al. 2003; Raza et al. 2005), so that deep-leached nitrogen and water (under AWD and upland irrigation) becomes less accessible. Macroporosity and pore connectivity may also be reduced in plough pans, causing poorer gas diffusivity and water availability (Stirzaker et al. 1996; Chen et al. 2014). Fewer macropores may also drastically affect root growth to subsoil (Rosolem et al. 2002), with negative impacts to crop productivity (Bengough et al. 2011).

Root elongation rate decreases with increasing penetration resistance (Reviewed by Bengough et al. 2011), leading to a $40 \%$ decrease in root length of rice when penetration resistance increases from $0.1 \mathrm{MPa}$ to $1.5 \mathrm{MPa}$ in a field (Hasegawa et al. 1985). This is observed for all crops, but the impacts vary between species. A hard layer in subsoil was found to reduce yield by $11-15 \%$ and $\mathrm{N}$ use efficiency by up to $6-22 \%$ in maize (Raza et al. 2005). A study conducted by Ishaq et al. (2003) reported that subsoil hardness reduces water use efficiency in wheat by $11 \%$ and cottom by $7 \%$. If deep rooting is inhibited by a plough pan, selecting crops for deep rooting characteristics (Atkinson et al. 2019) may be fruitless if varieties are still unable to reach the subsoil to access resources that improve crop growth (Kopke et al. 2015; Landl et al. 2016). A subsoil under cultivated topsoil can store huge amounts of water and nutrients to help meet the requirement of crops, even in drought conditions (Schneider et al. 2017). From a comprehensive review, Kautz et al. (2013) found that more than twothirds of the plant macronutrients $\mathrm{N}, \mathrm{P}$ and $\mathrm{K}$ can be found in subsoil.

Despite the limitations to root growth caused by mechanical impedance, roots are able to exploit biopores and cracks as preferential growth pathways. Deep soil cultivation practices in paddy rice can decrease plough pan strength by creating deep fractures that extend as the soil dries (McDonald et al. 2006), producing pathways for water and nutrient movement (Zhang et al. 2014). A review by Samson et al. (2002) suggested that mechanical rupturing of a plough pan increases yield of lowland rainfed rice in Bangladesh by 0.5 t/ha. Cracks are formed from nonbiological activities such as freezing, tillage or AWD (Ringrose-Voase 1996). On the other hand, biopores are created from decomposing plant roots and burrowing by fauna (Kautz 2015). Access of these different types of macropores by roots provides a possible solution for utilization of water and nutrients in the subsoil (Stirzaker et al. 1996; Bottinelli et al. 2016). The promotion of biopore formation has therefore been advocated as a sustainable option to help overcome the negative impacts of compaction to root growth (Kautz et al. 2013). Biopores are especially beneficial in drought periods for utilization of water (Gaiser et al. 2013).

Biopores leave round shaped voids in the soil (Kautz et al. 2014) that act as highways for plant roots to reach subsoil resources through shallower hard soil layers (Passioura 2002; McKenzie et al. 2009). Roots are attracted to the paths of least resistance produced by biopores in strong soils (Lynch and Wojciechowski 2015), resulting in faster growth and elongation deeper into the soil (Stirzaker et al. 
1996; Hirth et al. 2005). This was demonstrated eloquently in a controlled experiment with simulated biopores by Colombi et al. (2017) who found that without biopores, root dry weight in a compacted soil decreased by $36-72 \%$.

Round biopores and elongated, flat cracks, therefore provide different niches in the soil that allow roots to bypass the mechanical constraints of compacted layers like plough pans, in addition to providing habitats for microorganisms important to nutrient cycling (Passioura 1991). Although the importance of biopores and cracks as pathways for roots to overcome physical barriers in highly dense subsoil layers has frequently been emphasized, few studies have considered their importance when exploring the capacity of deep-rooting crop varieties to grow in compacted soils (Colombi et al. 2017). Moreover, no study that we could find has explored the impacts on rice, nor the differences between biopores and cracks. In rice production, both biopores and cracks can be manipulated by soil management, either by the crop rotation, extent of soil drying or the depth of cultivation.

Therefore, the main aim of this study was to investigate the effects of biopores and cracks on root growth through a compacted plough pan for deep and shallow rooting rice cultivars. We hypothesised that 1) deep rooting rice cultivars will exploit plough pan macroporosity more effectively than shallow rooting rice cultivars and 2) roots will respond differently to different types of macropores, with wide cracks allowing more abundant root penetration and branching than round biopores because of their greater surface area to volume.

\section{Materials and methods}

Plant materials and soil properties

A deep rooting rice genotype Black Gora (an aus type from the Rice Diversity Panel 1 (Zhao et al. 2011)) and a shallow rooting rice genotype IR64 (an indica type from the Oryza SNP set (McNally et al. 2009)) were used in this study. These two cultivars have been repeatedly shown to differ in root angle and depth in soil-filled rhizotron screens (e.g. Shrestha et al. 2014; Munasinghe and Price 2016). Soil was collected from the plough layer to $20 \mathrm{~cm}$ depth at a commercial farm in Insch, Aberdeenshire, UK. The soil was a sandy loam Dystric Cam-

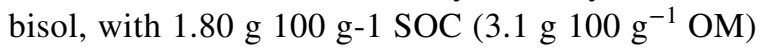
and a $\mathrm{pH}$ of 5.83 (Strachan et al. 2002). It has been used in a previous study for exploring root-interactions for rice (Shrestha et al. 2014).

Experimental setup and growth conditions

To provide controlled growing conditions, the experiment was conducted using packed soil columns (Fig. 1) planted with either of the two rice genotypes. The $43 \mathrm{~cm}$ depth of soil in the columns had realistic plough layer $(20 \mathrm{~cm})$ and subsoil $(23 \mathrm{~cm})$ depths to explore root growth. A diameter of $10.2 \mathrm{~cm}$ provided a compromise between the maximum possible size to allow for X-Ray CT imaging (Atkinson et al. 2020) (to appear in a follow-on paper), and to minimise soil volume artefacts influencing root growth. All soil columns had a $5 \mathrm{~cm}$ plough pan formed beneath the $20 \mathrm{~cm}$ ploughed layer.

The importance of biopores and cracks for root growth through the plough pan was explored by creating four soil structure treatments: i) Plough pan without macropores; ii) Plough pan with simulated biopores (round shape pores); iii) Plough pan with simulated cracks; and iv) Plough pan with simulated biopores and cracks. Each treatment was replicated four times. Soil preparation and details of the soil structure treatments are provided below and illustrated in Fig. 1.

The soil had a moisture content of $0.45 \mathrm{~g} \mathrm{~g}^{-1}$ in the field, so it was dried on the laboratory bench to $0.18 \mathrm{~g} \mathrm{~g}^{-1}$ moisture content to facilitate sieving. After drying, the soil was first broken up by hand and passed through $4 \mathrm{~mm}$ sieve, followed by further breaking of the soil to pass through a $2 \mathrm{~mm}$ sieve. On a subsample of soil, the moisture content of the Proctor Density (maximum bulk density) was determined (British Standards Institute 1990). This involved dropping a $4.5 \mathrm{~kg}$ Proctor Compaction Rammer (ELE International, Leighton Buzzard, UK) 20 times onto loose soil contained in a mould, for soil at five moisture contents starting at $0.18 \mathrm{~g} \mathrm{~g}^{-1}$. After each test, the soils were broken up, wetted with a spray bottle, mixed and then packed 
Fig. 1 Design of the core and arrangement of biopores and cracks for different soil structure treatments

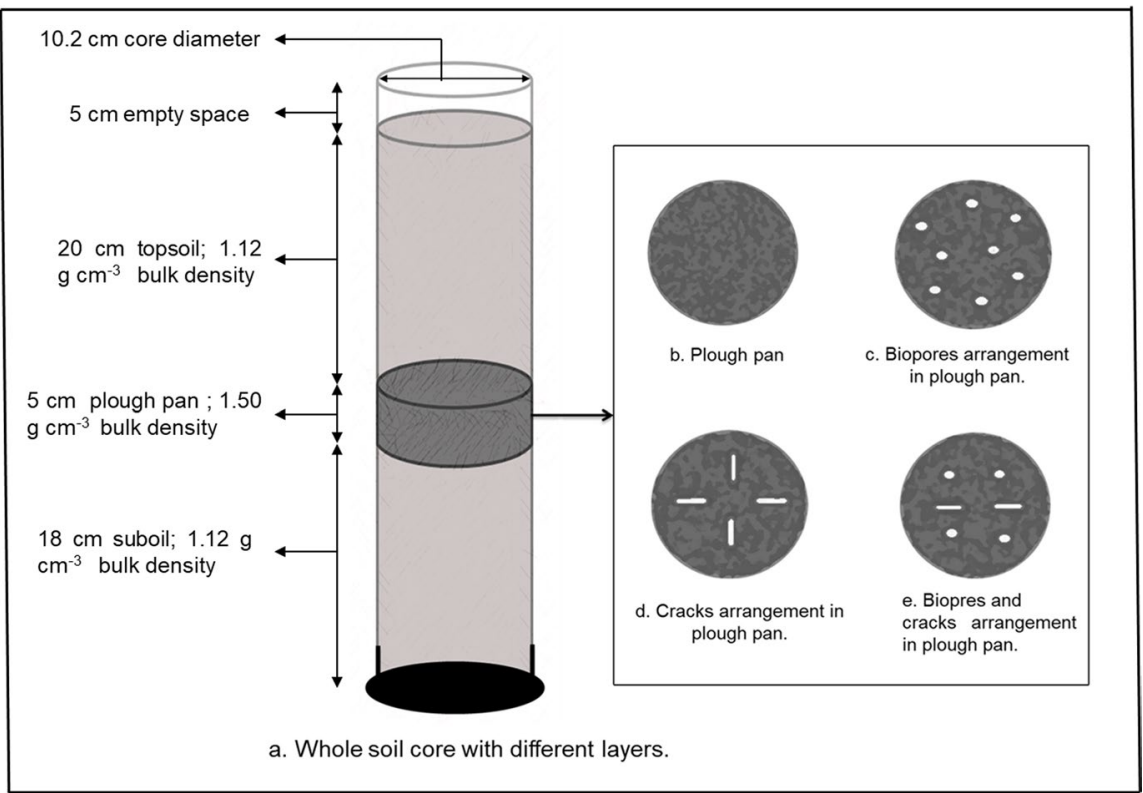

again into the mould. After measuring soil weight and volume, a small sample of soil was taken to measure water content. The Proctor Density of the soil was $1.53 \mathrm{~g} \mathrm{~cm}^{-3}$, which occurred at a water content was $0.20 \mathrm{~g} \mathrm{~g}^{-1}$.

The soil for packing into cores was wet to $0.20 \mathrm{~g} \mathrm{~g}^{-1}$ moisture content. It was packed into PVC cylinders (Fig. 1) that were lined with a $0.5 \mathrm{~mm}$ thick plastic sheet to aid removal of the soil column at the end of experiment. A cap at the base retained the soil and had a hole for drainage. Cores were packed to form a $20 \mathrm{~cm}$ topsoil, $5 \mathrm{~cm}$ plough pan and $18 \mathrm{~cm}$ subsoil layer. In packing the soil cores, the plough pan layer was packed first. For this purpose, a metal packer, with a circular flat surface that was slightly smaller than the internal diameter of the core was used. The base cap of the core was removed and the core was turned upside down with the packer surface set to the desired position of the top of the plough pan using a spacer. A $5 \mathrm{~cm}$ plough pan was packed in three layers using a $4.5 \mathrm{~kg}$ Proctor hammer that was dropped 20 times onto the soil, resulting in $1.50 \mathrm{~g} \mathrm{~cm}^{-3}$ bulk density with the surface of each layer roughened to improve homogeneity. Simulated biopores or cracks were inserted through the plough pan layer to form the different treatments. Biopores were made by using a round stainless-steel wire with $2.40 \mathrm{~mm}$ diameter. Cracks were created using a sharp rectangular metal sheet with $16.5 \mathrm{~mm}$ width and
$0.55 \mathrm{~mm}$ thickness. Either implement was inserted vertically using a grid so that the spatial arrangements of biopores and cracks were similar between replicates. These had eight biopores for the biopore treatment $(0.44 \%$ of the pan volume), four cracks for the cracks treatment $(0.54 \%$ of the pan volume), and four biopores and two cracks for the biopore and crack treatment $(0.49 \%$ of pan volume $)$. The total volume of simulated macropores in all the treatments were similar, with the volume of one crack approximately the volume of two biopores. Compared to biopores, cracks had $2.25 \times$ greater surface area and were $4.4 \times$ thinner. There was a control treatment without biopores or cracks through the plough pan.

Once the pan was formed, soil was then added to the upturned soil core in four layers, with each gently packed by using a round metal platen to $1.12 \mathrm{~g} \mathrm{~cm}^{-3}$ bulk density to form the $18 \mathrm{~cm}$ subsoil layer. The surface of each layer was roughened to ensure good adherence with adjacent layers and improve homogeneity. The cap at the base was then attached and the core turned over so that the top side was upward. The topsoil layer was packed in 4 layers to $1.12 \mathrm{~g} \mathrm{~cm}^{-3}$ bulk density using the same approach as the subsoil. On 6 separate smaller core samples packed the same way to $1.12 \mathrm{~g} \mathrm{~cm}^{-3}$ bulk density, the water contents at $-5 \mathrm{kPa}$ and $-20 \mathrm{kPa}$ were determined by first saturating the cores and then desaturating on a suction plate (Ecotech, Bonn, Germany). The water content at 
$-5 \mathrm{kPa}$ was $0.36 \mathrm{~g} \mathrm{~g}^{-1}$ and at $-20 \mathrm{kPa}$ it was $0.29 \mathrm{~g} \mathrm{~g}^{-1}$. Penetration resistance was measured on these cores at each water potential by a cone penetrometer with a $30^{\circ}$ cone opening angle and $1.87 \mathrm{~mm}^{2}$ base area fitted to a Z05 mechanical test frame (Zwick GmbH, Ulm, Germany). The penetrometer was inserted to a depth of $4 \mathrm{~mm}$ at a speed of $1 \mathrm{~mm} \mathrm{~min}^{-1}$. The average penetration resistance between 2 and $4 \mathrm{~mm}$ was used, which was $352 \mathrm{kPa}$ at $-5 \mathrm{kPa}$ water potential and $855 \mathrm{kPa}$ at $-20 \mathrm{kPa}$ water potential for topsoil and subsoil. Penetration resistance of the plough pan, determined by the same procedure for topsoil and subsoil, was $1.70 \mathrm{MPa}$ at $-5 \mathrm{kPa}$ water potential and $2.80 \mathrm{MPa}$ at $-20 \mathrm{kPa}$ water potential. The larger cores were placed in plastic pots and wetted to the $-5 \mathrm{kPa}$ water content by adding half of the desired amount of water at the base and rest of the water was added gradually on the top of the core.

Rice seeds were germinated on wet filter paper at $25^{\circ} \mathrm{C}$ for $48 \mathrm{~h}$. Each core was planted with two germinated rice seedlings of one of the genotypes at a depth of $4 \mathrm{~mm}$ from the soil surface. After 8 days of planting, the seedlings were reduced to one plant per core by removing the weakest plant. Soil water content was maintained at its $-5 \mathrm{kPa}$ value for the first two weeks of growth, and then adjusted to $-20 \mathrm{kPa}$ water potential. This was done by weighing the cores once a day for the first two weeks and once every two days for the rest of the growth period, adding water by gently spraying to obtain the desired water content. All the plants were grown for a period of 33 days. During the growth period, the soil cores were kept in a tropical greenhouse with day/night temperatures of 28/24 ${ }^{\circ} \mathrm{C}$, light intensity $464 \mu \mathrm{mol} \cdot \mathrm{m}^{-2} \cdot \mathrm{s}^{-1}$ and $11 \mathrm{~h}$ photoperiod. Plant height, number of leaves and tillers were recorded at harvesting.

\section{Harvesting}

At harvest, all the shoots were cut at the soil surface and fresh weights of shoots were recorded. After recording the fresh weight, shoots were dried in an oven at $70{ }^{\circ} \mathrm{C}$ for $24 \mathrm{~h}$. Intact soil was extracted from the core by removing the base of the soil column and pushing the soil in the plastic liner gently out of the PVC cylinder using the same plunger that was used for packing. The plastic liner was pealed back from the surface of the intact soil. Each core was then separated into topsoil (to the surface of the plough pan), plough pan and subsoil (below the plough pan) layers by gently cutting with a hacksaw. The roots of topsoil and subsoil layers were washed using tap water over a $2 \mathrm{~mm}$ sieve, with soil brushed away from roots carefully to minimise damage. The cleaned root samples were kept in $50 \%$ ethanol at $4{ }^{\circ} \mathrm{C}$. The plough pan layer for each core was frozen at $-18{ }^{\circ} \mathrm{C}$ for 3 weeks and then we followed the approach presented by Loades et al. (2010) to visualise the number of roots growing through either the plough pan, cracks or biopores. This sprayed warm water onto the frozen soil surface, removing about $5 \mathrm{~mm}$ of soil so that roots were exposed. Photographs of the bottom surface of plough pan were captured using a DSLR camera fitted with an SMC PENTAX-DFA MACRO 1:2.8 $100 \mathrm{~mm}$ lens, set to 8 aperture, ISO of 200 and resolution of $6016 \times 4000$ pixel. Two photographic lights were used.

\section{Root measurement}

Washed roots were placed in a plexiglass tray (100 by $200 \mathrm{~mm}$ ) with a 5 to $6 \mathrm{~mm}$ deep layer of water. The roots were spread out with tweezers to reduce overlapping and then scanned using an Expression 10000XL scanner (Epson, Suwa, Japan) at 800 DPI. Total root length, root volume, average diameter, branch number and tip number for all roots in each layer were determined by the root analysis software, WinRhizo (Version 2013e) (Regent Instrument Canada Inc.). Root number was counted manually in different layers of the soil core but only includes seminal and crown roots. The number of roots growing through different macropores in pan layer were counted from the plough pan images captured by the camera, as described in the previous section. Cutting of the soil into different layers could influence the measurement of root tips. There was no evidence of root fragments in the washed roots, so cutting was assumed to have minimal influence on branch number or root numbers.

\section{Statistical analysis}

Statistical analysis was performed using $\mathrm{R}$ (version 4.0.3) (Team 2020a) in the R Studio (version 1.3.1093) (Team 2020b) environment. The normality of residuals and assumptions of the homogeneity of variances were checked by the Shapiro-Wilk and 
Bartlett tests, respectively prior to any further statistical tests. Two-way ANOVA was conducted with variety and soil structure as the two factors, and their interactions were also examined. Post hoc analysis was performed by the LSD test for significant differences between treatments at $\mathrm{P}<0.05$.

\section{Results}

Different above ground parameters

All the above ground parameters (plant height, number of leaves, tillers, shoot fresh and dry weight) differed significantly between rice varieties but there were no significant effects of soil structures (Table 1). The height of plants was around 38-51\% taller in Black Gora than IR64 but the number of tillers was double in IR64 than Black Gora (Table 2). The number of leaves was 1.60-1.85 times greater in IR64 than Black Gora. About 8-32\% greater shoot dry weight was recorded for Black Gora than IR64 (Table 2).

Root length density

The deep rooting Black Gora genotype benefitted considerably from the presence of either biopores or cracks, resulting in 40\%-67\% greater total root length density within the entire soil columns compared to when they were not present (Fig. 2a). This was markedly greater than for the shallow rooting IR64 genotype, which produced only $6 \%-13 \%$ greater total root length density within the entire soil columns in the presence of biopores or cracks (Fig. 2a). An analysis of the topsoil, plough pan and subsoil layers found that root length density in the topsoil did not differ between genotypes $(\mathrm{p}>0.05)$, but around 15\%-20\% less root length density was observed when biopores or cracks were absent (Fig. 2a). Root length density in the plough pan layer differed between genotypes and soil structure treatments (Fig. 2b). For Black Gora, root length density in the plough pan layer increased by $316 \%$ with biopores and $569 \%$ with cracks (Fig. 2b). On the other hand, for IR64 root length density in the plough pan layer increased by $301 \%$ with biopores and $488 \%$ with cracks (Fig. 2 b). In the subsoil, root length density for Black Gora increased by $151 \%$ with biopores and $79 \%$ with cracks (Fig. 2c). For IR64, however, root length density in subsoil did not differ significantly under biopores and cracks treatments (Fig. 2c).

Cracks were more effective than biopores at serving as growth channels through the plough pan than the biopores or biopore-cracks treatment for either genotype (Fig. 2b). For deep rooting Black Gora, root length density in the plough pan layer for the crack treatment was $60 \%$ greater than for biopores

Table 1 Above ground parameters of two rice varieties grown under different treatments

\begin{tabular}{|c|c|c|c|c|c|c|}
\hline & Treatments & Plant height $(\mathrm{cm})$ & Number of leaves & Number of tillers & $\begin{array}{l}\text { Shoot fresh } \\
\text { weight }(\mathrm{g})\end{array}$ & $\begin{array}{l}\text { Shoot dry weight } \\
(\mathrm{g})\end{array}$ \\
\hline \multirow[t]{4}{*}{ IR64 } & Plough pan & $47.75(1.31)$ & $26.75(0.85)$ & $8.25(0.25)$ & $5.29(0.27)$ & $1.63(0.11)$ \\
\hline & Biopore & $48.25(0.63)$ & $28.25(0.75)$ & $8.75(0.25)$ & $5.67(0.18)$ & $1.73(0.04)$ \\
\hline & Crack & $47.75(0.75)$ & $27.50(0.64)$ & $9.00(0.00)$ & $5.55(0.19)$ & $1.75(0.06)$ \\
\hline & Biopore-crack & $47.50(0.29)$ & $26.75(1.44)$ & $8.25(0.63)$ & $5.28(0.24)$ & $1.56(0.07)$ \\
\hline \multirow[t]{4}{*}{ Black Gora } & Plough pan & $66.00(1.29)$ & $14.50(0.50)$ & $4.50(0.29)$ & $6.37(0.56)$ & $1.80(0.16)$ \\
\hline & Biopore & $70.50(2.40)$ & $15.25(0.25)$ & $5.00(0.00)$ & $6.98(0.54)$ & $1.98(0.14)$ \\
\hline & Crack & $69.25(2.25)$ & $15.00(0.41)$ & $4.50(0.29)$ & $6.81(0.42)$ & $1.89(0.10)$ \\
\hline & Biopore-crack & $71.75(2.87)$ & $16.50(0.64)$ & $5.25(0.25)$ & $7.21(0.15)$ & $2.07(0.06)$ \\
\hline \multicolumn{7}{|c|}{ Analysis of variance } \\
\hline Variety (V) & & $317 * * *$ & $494 * * *$ & $300 * * *$ & $31 * * *$ & $14 * * *$ \\
\hline $\begin{array}{l}\text { Soil Structure } \\
\quad \text { (SS) }\end{array}$ & & NS & NS & NS & NS & NS \\
\hline $\mathrm{V} \times \mathrm{SS}$ & & NS & NS & NS & NS & NS \\
\hline
\end{tabular}

Numbers in brackets are the standard error of the mean. For ANOVA, values reported are the f-values and asterisk indicating the level of significance. NS means non-significant at the $\mathrm{P}=0.05$ level and $* * * \mathrm{p}<0.001$ 
Table 2 Statistical analysis of root parameters for 2 varieties grown under 4 different soil structures treatments
Values reported are the f-values from the ANOVA and asterisk indicating the level of significance

$N S$ not significant

$* \mathrm{p}<0.05, * * \mathrm{p}<0.01$ $* * * \mathrm{p}<0.001$

\begin{tabular}{|c|c|c|c|c|}
\hline Layers & Root parameter & Variety (V) & Soil structure (SS) & $\mathrm{V} \times \mathrm{SS}$ \\
\hline \multirow[t]{6}{*}{ Total } & Root length density $\left(\mathrm{cm} \mathrm{cm}^{-3}\right)$ & $24.50 * * *$ & $4.80 * *$ & $3.03 *$ \\
\hline & Root number & NS & $5.53 * *$ & NS \\
\hline & Diameter $(\mathrm{mm})$ & $21.57 * * *$ & $0.03 * *$ & NS \\
\hline & Volume $\left(\mathrm{cm}^{3}\right)$ & NS & NS & NS \\
\hline & Number of tips & $28.87 * * *$ & $6.82 * * *$ & $4.65^{* *}$ \\
\hline & Number of branch & $14.52 * * *$ & $5.78 * * *$ & $0.04 *$ \\
\hline \multirow[t]{6}{*}{ Topsoil } & Root length density $\left(\mathrm{cm} \mathrm{cm}^{-3}\right)$ & NS & $4.65 *$ & NS \\
\hline & Root number & $42.02 * * *$ & NS & NS \\
\hline & Diameter $(\mathrm{mm})$ & $9.75 * *$ & NS & NS \\
\hline & Volume $\left(\mathrm{cm}^{3}\right)$ & $4.77 *$ & NS & NS \\
\hline & Number of tips & NS & $4.22 *$ & NS \\
\hline & Number of branch & NS & NS & NS \\
\hline \multirow[t]{9}{*}{ Pan } & Root length density $\left(\mathrm{cm} \mathrm{cm}^{-3}\right)$ & $15.80 * * *$ & $14.37 * * *$ & NS \\
\hline & Root number & NS & $7.44 * *$ & NS \\
\hline & Diameter $(\mathrm{mm})$ & NS & $5.16^{* *}$ & NS \\
\hline & Volume $\left(\mathrm{cm}^{3}\right)$ & $4.99 *$ & $8.69 * * *$ & NS \\
\hline & Number of tips & $30.35 * * *$ & $14.87 * * *$ & $4.19 *$ \\
\hline & Number of branch & $15.30 * * *$ & $12.02 * * *$ & NS \\
\hline & Biopores roots & $34.91 * * *$ & $103.45 * * *$ & $14.91 * * *$ \\
\hline & Cracks roots & $18.69 * * *$ & $38.60 * * *$ & $6.60 * *$ \\
\hline & Non-macropores roots & $8.93 * *$ & $10.14 * * *$ & NS \\
\hline \multirow[t]{6}{*}{ Subsoil } & Root length density $\left(\mathrm{cm} \mathrm{cm}^{-3}\right)$ & $78.89 * * *$ & $3.42 *$ & $3.37 *$ \\
\hline & Root number & $58.69 * * *$ & $5.18 * *$ & $4.68^{*}$ \\
\hline & Diameter $(\mathrm{mm})$ & $19.08 * * *$ & NS & NS \\
\hline & Volume $\left(\mathrm{cm}^{3}\right)$ & $67.47 * * *$ & NS & NS \\
\hline & Number of tips & $52.56 * * *$ & NS & NS \\
\hline & Number of branch & $56.21 * * *$ & $2.8^{*}$ & NS \\
\hline
\end{tabular}

and $10 \%$ more than for biopore-cracks (Fig. 2b). The crack treatment for IR64 had root length density in the plough pan layer that was $47 \%$ greater than for biopores and $89 \%$ greater than for bioporecracks (Fig. 2b). Despite cracks resulting in longer roots within the plough pan, biopores had the biggest impact on subsoil root length density (Fig. 2c). A sharp decrease in root length density occurred if biopores or cracks were absent (Fig. 2b and c).

\section{Root number}

The presence of both biopores and cracks in the plough pan resulted in the largest number of total roots over the entire depth of soil, followed by just cracks and then just biopores, resulting in $24-46 \%$ greater root number with Black Gora and 18-31\% greater root number with IR64 compared to no macropores (Fig. 3a). Although the total number of roots over the entire depth of the core did not differ between Black Gora and IR64 (Fig. 3a), variety had a marked effect when topsoil, plough pan and subsoil layers were analysed separately. In the topsoil, root number was unaffected by biopore or crack presence in the plough pan below (Table 1), but differed markedly between the deep rooting and shallow rooting genotypes (Fig. 3a).

This variety difference disappeared in the plough pan, where soil structure caused a marked difference, with around $206 \%$ more roots found in the crack treatment compared to the intact plough pan for Black Gora (Fig. 3b). In the subsoil, deep rooting Black Gora had markedly more roots than shallow rooting IR64 (Fig. 3c). Biopores and cracks presence also had a large impact on root number (Table 3, Fig. 3c) and had a strong interaction with variety in subsoil. 
Fig. 2 Total root length density in cm cm-3 for different rice varieties under different soil treatments. Total root length density in different layers of soil core (a), root length density in plough pan layer of soil core (b) and root length density in subsoil layer of soil core (c). Error bars are standard error of the mean. $\mathrm{BG}=$ Black Gora, $\mathrm{IR}=\mathrm{IR64}$. Pan treatment is plough pan in the absence of macropores
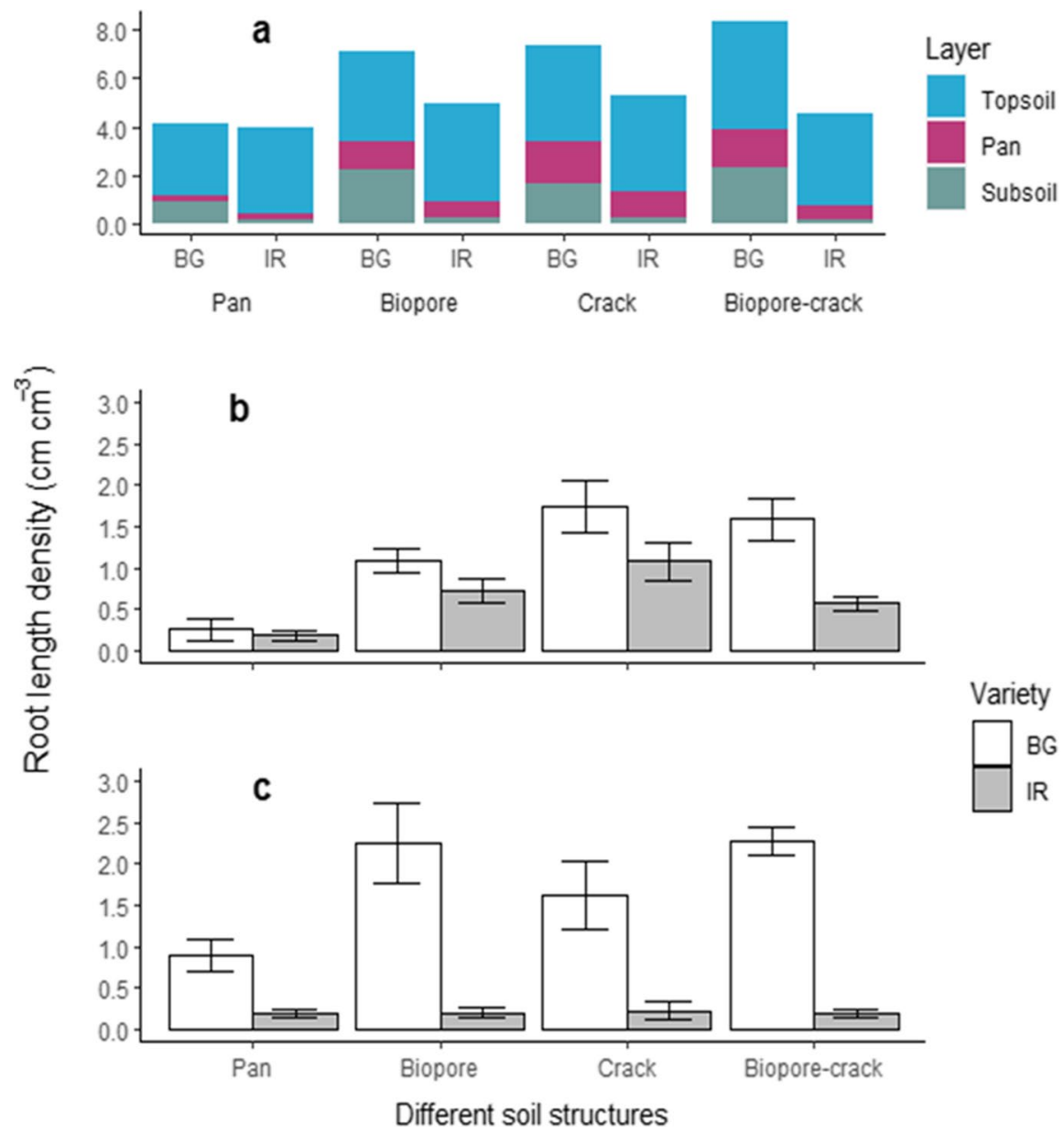

Rice root growth through cracks and biopores

Further analysis from a visual examination of the number of roots in the plough pan growing through either the bulk soil, biopores or cracks revealed that not only does macropore presence greatly enhance root numbers, but that macropore structure also has a large impact (Figs. 4 and 5). Either biopores or cracks (Figs. 4 and 5) caused large increases to root numbers, but when both biopores and cracks are present, double the number of roots grew in cracks than biopores (Fig. 4).

\section{Other root parameters}

Macropores formed from either biopores or cracks resulted in about 5-7 times greater number of root tips and 4.5-8 times more root branching than the plough pan with no macropores treatment (Table 3 ).
In the separate layers, these impacts were found for the plough pan and subsoil, but not in the topsoil (Table 2). Root volume and average diameter differed between rice varieties in the topsoil. In the plough pan, root volume and average diameter varied among different soil structures (Table 2). Deeper in the subsoil, soil structure did not affect diameter and volume of roots (Table 2). However, there was a strong effect of variety and soil structure on the number of root branches and tips (Table 2) in the plough pan. Black Gora produced more root tips and branches than IR64 within the plough pan layer (Table 3). The presence of macropores increased root tip numbers by 4.5-8.4 times in Black Gora and 4.0-7.5 times in IR64, compared to no macropore treatments (Table 3). But in subsoil, the number of root tips was only affected by varieties and not by soil structure. Deep rooting Black Gora produced 5-14 times greater root branching and 5-16 times 
Fig. 3 Total number of crown and seminal roots for different rice varieties under different soil treatments as calculated from WinRHIZO: total number of roots in different layers of soil core (a), number of roots in plough pan layer of soil core (b) and number of roots in subsoil layer of soil core (c). Error bars are standard error of the mean. $\mathrm{BG}=$ Black Gora, $\mathrm{IR}=\mathrm{IR} 64$. Pan treatment is plough pan in the absence of macropores
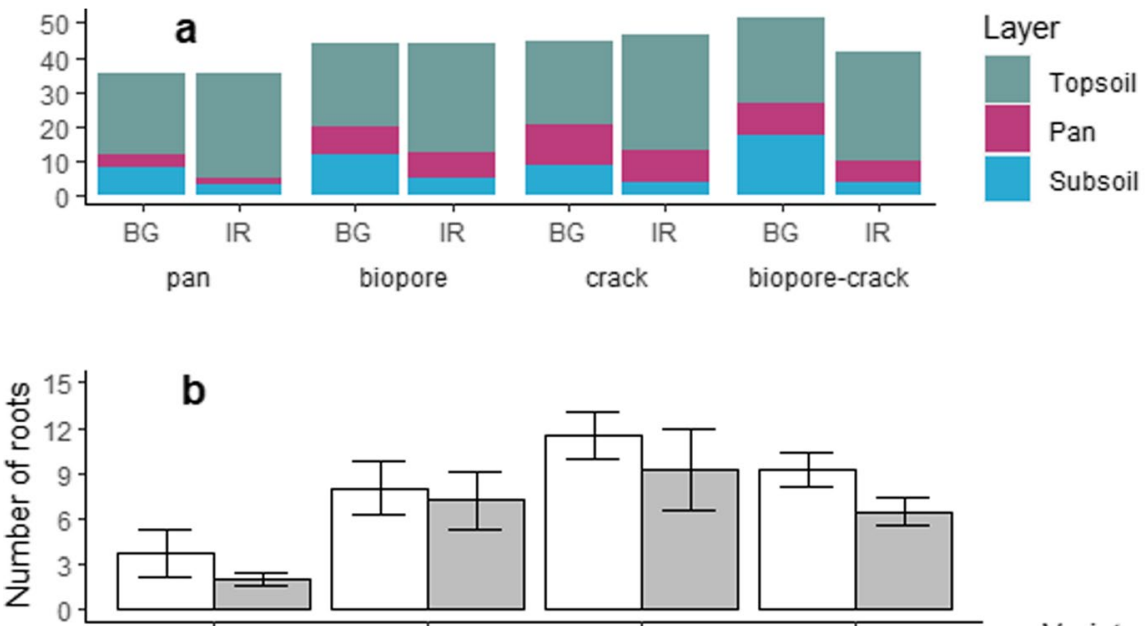

Variety

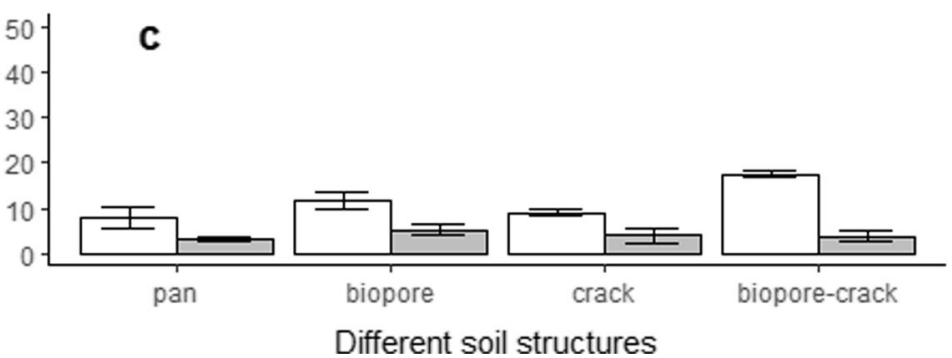

greater tip numbers than shallow rooting IR64 in subsoil (Table 3 ). Whereas biopores and cracks significantly increased root tips, volume and branching in the plough pan layer, there were no impacts in the subsoil layer of the soil core (Table 2).

\section{Discussion}

Cracks were found to be far better than biopores for rice root growth through plough pans, with a deep rooting variety being far more responsive to macropore presence. This research suggests that simple quantification of macroporosity may be insufficient, and that macropore shape has a large impact on root access and branching. Measurements of mechanical impedance may be inadequate to predict subsoil access by roots, as spatially sparse macropores provide preferential growth pathways (Stirzaker et al. 1996) but do not change the bulk strength of soil measured by a much larger and stiff penetrometer.
Roots of different rice varieties responded differently with different soil structures

The two rice varieties used in this study showed different performances for exploring the biopores and cracks in a compacted plough pan. We found that the deep rooting variety (Black Gora) explored macropores more efficiently by altering root characteristics than the shallow rooting variety (IR64). These different responses between the rice varieties may be due to their capacity for root branching, as the greater root branches in Black Gora compared to IR64 (Table 3) may improve chances of a root finding a macropore. Greater chances of finding macropores by the roots of Black Gora may be also due to their differences in root angle, as Black Gora has more steeper root angles than IR64 (Shrestha et al. 2014). The strong positive gravitropism of a deep rooting cultivar (Araki and Iijima 2001) may be another reason for exploiting macropores more efficiently than a shallow rooting cultivar. Root architecture is well known to influence macropore access between plant species, but to our 
Table 3 Effects of variety and soil structure on different root parameters in different layers of soil cores

\begin{tabular}{|c|c|c|c|c|c|c|}
\hline Core layers & Varieties & Treatments & Volume $\left(\mathrm{cm}^{3}\right)$ & Avg. Diameter (mm) & Number of tips & Number of branches \\
\hline \multirow[t]{8}{*}{ Total } & \multirow[t]{4}{*}{ IR64 } & Plough pan & $2.85(0.080)$ & $0.79(0.020)$ & $37,004(2712)$ & $76,785(2193)$ \\
\hline & & Biopore & $3.21(0.150)$ & $0.74(0.040)$ & $42,644(2277)$ & $92,035(5979)$ \\
\hline & & Crack & $3.13(0.340)$ & $0.74(0.050)$ & $43,977(1434)$ & $88,897(6049)$ \\
\hline & & Biopore-crack & $2.86(0.140)$ & $0.71(0.040)$ & $39,558(4265)$ & $83,667(4430)$ \\
\hline & \multirow[t]{4}{*}{ Black Gora } & Plough pan & $2.59(0.020)$ & $0.71(0.040)$ & $36,806(4953)$ & $69,593(14,976)$ \\
\hline & & Biopore & $3.43(0.570)$ & $0.62(0.020)$ & $65,278(10,950)$ & $120,330(20,891)$ \\
\hline & & Crack & $3.60(0.380)$ & $0.63(0.020)$ & $60,628(3484)$ & $123,638(8545)$ \\
\hline & & Biopore-crack & $3.63(0.160)$ & $0.59(0.010)$ & $75,861(2735)$ & $138,310(3210)$ \\
\hline \multirow[t]{8}{*}{ Topsoil } & \multirow[t]{4}{*}{ IR64 } & Plough pan & $2.65(0.062)$ & $0.24(0.007)$ & $35,152(2690)$ & $74,268(2717)$ \\
\hline & & Biopore & $2.92(0.166)$ & $0.24(0.004)$ & $39,449(2500)$ & $87,254(6249)$ \\
\hline & & Crack & $2.81(0.318)$ & $0.23(0.008)$ & $39,934(1283)$ & $82,545(5903)$ \\
\hline & & Biopore-crack & $2.64(0.134)$ & $0.23(0.005)$ & $37,004(4208)$ & $78,990(4648)$ \\
\hline & \multirow[t]{4}{*}{ Black Gora } & Plough pan & $2.06(0.165)$ & $0.23(0.008)$ & $28,467(2784)$ & $56,882(12,416)$ \\
\hline & & Biopore & $2.34(0.390)$ & $0.22(0.006)$ & $39,082(5363)$ & $83,647(11,642)$ \\
\hline & & Crack & $2.65(0.304)$ & $0.22(0.010)$ & $40,310(2685)$ & $92,772(7879)$ \\
\hline & & Biopore-crack & $2.51(0.152)$ & $0.208(0.004)$ & $47,971(2015)$ & $98,513(4155)$ \\
\hline \multirow[t]{8}{*}{ Pan } & \multirow[t]{4}{*}{ IR64 } & Plough pan & $0.04(0.012)$ & $0.28(0.010)$ & $305(97)$ & $505(191)$ \\
\hline & & Biopore & $0.14(0.036)$ & $0.23(0.022)$ & $1551(308)$ & $2437(450)$ \\
\hline & & Crack & $0.17(0.043)$ & $0.22(0.008)$ & 2241(439) & 3879(997) \\
\hline & & Biopore-crack & $0.11(0.022)$ & $0.24(0.012)$ & 1087(134) & $2040(401)$ \\
\hline & \multirow[t]{4}{*}{ Black Gora } & Plough pan & $0.06(0.025)$ & $0.26(0.034)$ & $598(308)$ & $844(466)$ \\
\hline & & Biopore & $0.16(0.034)$ & $0.21(0.013)$ & $2832(393)$ & $3801(562)$ \\
\hline & & Crack & $0.26(0.043)$ & $0.21(0.003)$ & 4327(766) & $7107(1531)$ \\
\hline & & Biopore-crack & $0.19(0.030)$ & $0.19(0.007)$ & 4478(697) & $6321(1127)$ \\
\hline \multirow[t]{8}{*}{ Subsoil } & \multirow[t]{4}{*}{ IR64 } & Plough pan & $0.15(0.037)$ & $0.27(0.011)$ & $1546(432)$ & $2012(515)$ \\
\hline & & Biopore & $0.15(0.028)$ & $0.26(0.028)$ & $1643(569)$ & $2343(778)$ \\
\hline & & Crack & $0.15(0.067)$ & $0.28(0.037)$ & 1801(945) & 2472(1308) \\
\hline & & Biopore-crack & $0.11(0.038)$ & $0.23(0.027)$ & 1467(404) & $2636(245)$ \\
\hline & \multirow[t]{4}{*}{ Black Gora } & Plough pan & $0.47(0.084)$ & $0.22(0.018)$ & $7740(2640)$ & $11,866(3639)$ \\
\hline & & Biopore & $0.93(0.183)$ & $0.19(0.014)$ & $23,363(6182)$ & $32,881(9021)$ \\
\hline & & Crack & $0.69(0.187)$ & $0.19(0.007)$ & $15,991(5043)$ & $23,758(6987)$ \\
\hline & & Biopore-crack & $0.93(0.076)$ & $0.19(0.005)$ & $23,412(2417)$ & $33,475(2484)$ \\
\hline
\end{tabular}

Roots are cut between layers, which may affect accuracy of root tip measurements. Numbers in the brackets are standard error of the mean

knowledge this is the first direct evidence between contrasting genotypes.

Early work by Dexter (1986) found that monocotyledons that have several main roots per plant access macropores more than dicotyledonous plants that have only one main root axis. A similar trend was observed by Passioura (1991), who found that greater lateral root numbers for sunflower compared to sorghum improved root penetration into soil peds. Species differences related to root branching were also observed by Colombi et al. (2017), who conducted a controlled experiment with simulated macropores and different crop species. They found maize roots accessed simulated macropores more than wheat and soybean, concluding that some species may have a greater capacity to sense macropores, possibly through oxygen gradients (Colombi et al. 2017). Athmann et al. (2013) found that different species of crop utilize biopores in different ways: barley exploit biopores by using thin vertical roots, whereas oilseed 
Fig. 4 Total number of roots through macropore (Biopore root \& crack root) and non-macropore (Pan root) for different rice varieties under different soil treatments as calculated from the pan images. Error bars are standard error of the mean. Pan root means roots through bulk soil/nonmacropore root. $\mathrm{BG}=$ Black Gora, IR = IR64. Pan treatment is plough pan in the absence of macropores
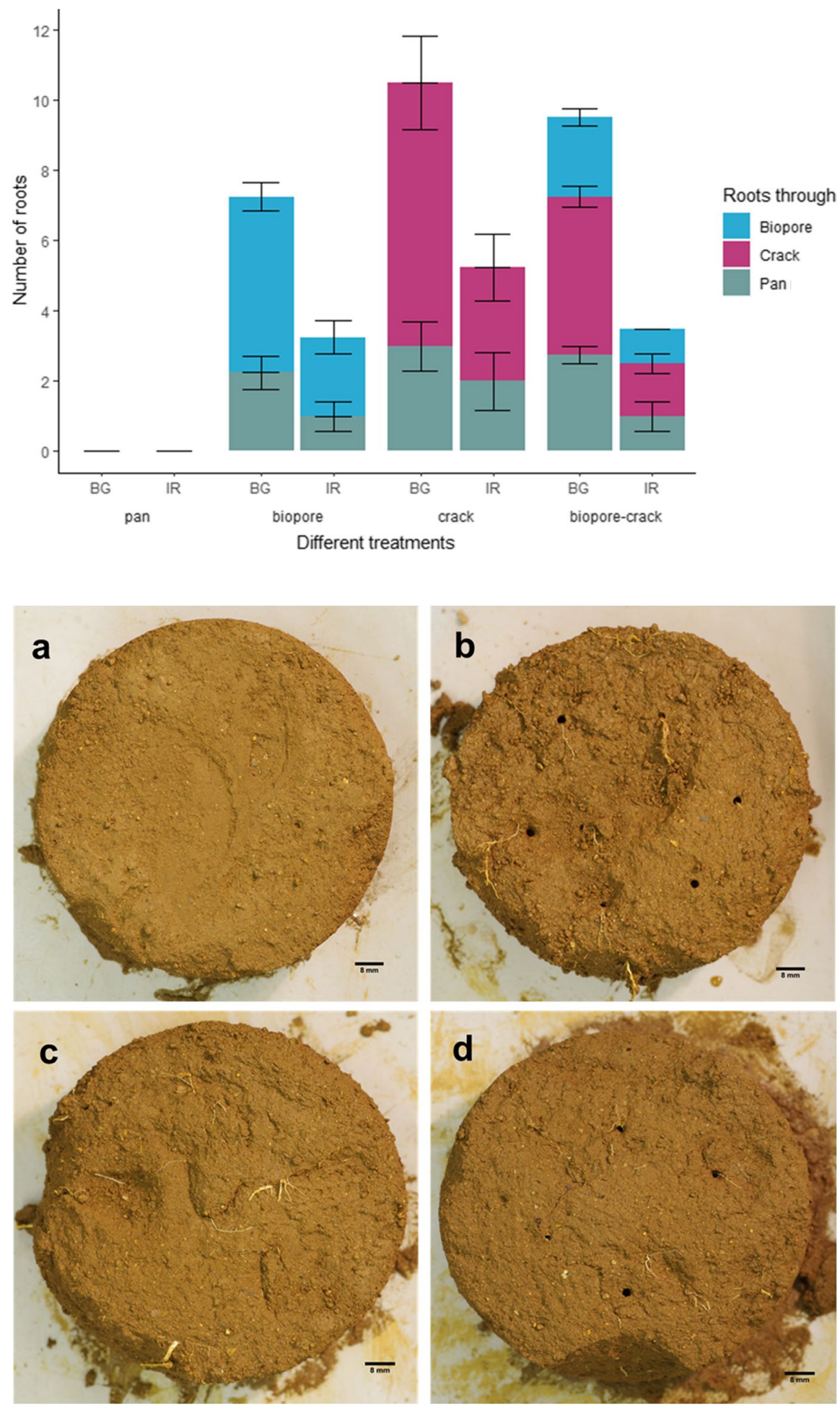

Fig. 5 Photographs of the bottom surface of plough pans after harvesting for different treatments. Plough pan without macropores (a), plough pan with artificial biopores (b), plough pans with artificial cracks (c), and plough pan with artificial biopores and cracks (d) 
rape established a relationship using lateral roots. On the other hand, a study conducted by Atkinson et al. (2020) showed that the response of roots to simulated macropores was not significantly different between two wheat genotypes, but this may be due to their use of a nearly isogenic wheat line. In our experiment, we used two rice genotypes with highly contrasting root systems and the results suggest that deep rooting is a key trait for a rice plant to exploit existing pore networks in hard subsoil more effectively. Our first hypothesis, that deep rooting rice cultivars will exploit plough pan macroporosity more effectively than shallow rooting rice cultivars was fully supported by our results. Besides the genotypic effects of root growth through macropores, soil physical conditions influence root branching greatly because root branching responds highly plastically to different soil environments (Fang et al. 2013). Many studies have found that compaction reduces the number of lateral roots or branching in cereals and soybean (Grzesiak et al. 2013; Coelho Filho et al. 2013; Colombi and Walter 2017). As a result, the plasticity of roots across different soil environments may restrict macropore access. A study conducted by Fang et al. (2018) found that rice root branching increased greatly in the presence of aggregated soil compared to non-aggregated soil. Since the roots need to grow through topsoil to reach biopores or cracks in subsoil, topsoil could be managed to influence branching and improve macropore access. These processes are poorly understood, but unravelling the interaction between genotypic and environmental drivers of root architecture in rice and other crops could help develop farming systems that use resources far more effectively.

Relationship between simulated macropores in soil hard layer and different root parameters

Although penetration resistance and bulk density were the same across our treatments, we found a huge impact of macropores in the plough pan on root branching (Table 2), number (Fig. 3) and RLD (Fig. 2). This agrees with Colombi et al. (2017) who used simulated macropores similar to our biopores and explored the response maize, soybean and wheat. In barley, Pfeifer et al. (2014) showed with the help of $\mathrm{X}$-ray computed tomography that macropores in hard subsoil influenced root growth as well as root branching. Similarly, Atkinson et al. (2020) reported that macropores provide an important strategy of wheat roots to bypass compacted subsoil. Although some soil physical properties, such as hydraulic conductivity and air permeability, can increase markedly in compacted soil if they contain simulated macropores (Colombi \& Walter 2017; Stirzaker et al. 1996), the penetration resistance that impedes root growth in bulk soil remains the same (Colombi et al. 2017).

The better performance of roots in plough pans containing macropores may be due to the capacity of plant roots to sense different soil environmental conditions, leading to preferential growth through these more favourable zones of soil (Passioura 2002; Pfeifer et al. 2014). Stirzaker et al. (1993) reported that roots bend when they experience physical barriers, leading to growth towards weak zones such as biopores. In another study, Stirzaker et al. (1996) also suggested that lateral roots tackle adverse soil structure more efficiently than axial roots by branching, which would increase the chances of roots hitting macropores. Greater branching or root numbers provide good indicators to explain plant tolerance in compacted conditions (Colombi and Walter 2017). Therefore, macropores in a compacted plough pan could increase the tolerance of crops in unfavourable soil structures by influencing root branching.

Our results also showed that after roots grew through macropores in the plough pan-, the root number (Fig. 2), branching (Table 2) and RLD increased significantly in the subsoil. A few roots passing through macropores in unfavourable plough pans can therefore proliferate at depth to capture resources more effectively. Different studies have shown that roots from a range of crop species are attracted by macropores (Stirzaker et al. 1996; White and Kirkegaard 2010; Pfeifer et al. 2014), but to the best of our knowledge this is the first study with rice. In naturally structured soil, another reason for greater root growth in macropores could be their positive influence on releasing nutrients due to enhanced oxygen, microbial activities and biochemical reactions compared to bulk soil (Horn and Smucker 2005; Don et al. 2008; Bauke et al. 2016).

Rice root responded differently to different types of macropores

Although the volume of macropores were the same between biopore and crack treatments, they resulted 
in significant differences in root growth through the plough pan and subsequent root proliferation into the subsoil. Cracks likely produced significantly larger root length density and higher number of roots than biopores because they had 2.25 times greater surface area. This increases the likelihood that roots will randomly hit a crack compared to a biopore. Moreover, cracks were thinner than biopores, possibly leading to greater root-soil contact that can enhance nutrient and water uptake from the soil (Athmann et al. 2013). We also found greater root branching in cracks than biopores in the plough pan, leading to enhanced root length density and root numbers. This agrees with research on wheat in field conditions by White and Kirkegaard (2010) who found that cracks with less thickness than biopore diameter produced greater root branching in cracks than biopores. Inserting the cracks into the plough pan likely led to increased mechanical damage of surrounding soil, leading to $56 \%$ more roots growing through bulk soil in the plough pan in comparison to the biopore treatment (Fig. 4). Although care was taken to minimise damage when inserting the macropores and the soil was fairly plastic, some microcracking was evident. Deeper tillage would also increase mechanical damage to produce a range of crack sizes that could promote root growth (McDonald et al. 2006). Beneath the plough pan, in the subsoil, the biopore treatment produced longer and more abundant roots with greater branching than cracks treatment. (Fig. 3 and Table 3). Up to 6 roots were crowded together in an individual biopore, compared to up to 8 roots that were spread more in a crack. Biopores had more crowded roots than cracks and root growth was observed through only a few biopores, which may have promoted branching after roots reached the loose subsoil. Clustering root growth through few biopores (Fig. 5) in compacted soil is a common phenomenon and water and nutrient extraction become slowed due to clumped root growth in biopores (Passioura 1991). But the improved root branching was found when these clustered roots reached to loose subsoil possibly due to higher extraction of water and nutrient from subsoil.

Macropores clearly have a large impact on root growth through compacted layers like plough pans, as has been shown in a large body of research. As a result, simple measurements of mechanical impedance may be insufficient to characterise physical conditions for root growth due to the capacity of roots to bypass strong soil via spatially discrete macropores that do no influence bulk strength. Not only is the presence of macropores important to quantify, but also the shape and connectivity of macropores. Deep tillage to fracture plough pans provides a mechanical means to improve deep rooting through cracks (McDonald et al. 2006), which for rice should be exploited much better by deep rooting versus shallow rooting genotypes. Drying of soil, either through AWD in paddy systems or in rotations to upland rice, can also promote crack growth deep into subsoil (Yoshida and Hallett 2008). We also observed that a few roots were able to penetrate compacted soil, which would leave biopores that can be exploited by subsequent crops.

This was a model study conducted to disentangle soil physical limitations that may be typical in a lowland to upland rice rotation production system. Macropore properties are different in natural conditions as pore walls can be enriched with organic matter from roots of previous crops or other faunal residues (Kautz et al. 2013). Naturally structured soils also have a more tortuous and complex macropore structure, so future research on deep rooting by rice should explore intact soils using X-Ray CT to visualise root-soil interactions, following approaches used for other crops (Pfeifer et al. 2014; Colombi et al. 2017; Zhou et al. 2021). Recent years have seen a move from flooded rice to AWD (Ishfaq et al. 2020), so pan properties may be more important to consider as deep rooting will benefit crop performance (Fang et al. 2018). There is also a shift towards conservation agriculture in rice where reduced tillage will leave more macropores for roots to exploit (Chaki et al. 2021).

\section{Conclusions}

A deep rooting rice genotype was far more effective at exploiting macropores in a plough pan to reach subsoil. Not only did the presence of macropores influence deep rooting, but also macropore shape. Compared to biopores, cracks allowed a greater number of roots to penetrate a plough pan, and also enhanced branching within the plough pan because their shape increased root-soil contact and the likelihood of being 'found'. However, a small number of 
crowded roots growing through biopores proliferated more than roots growing through cracks once unimpeded subsoil with better growing conditions was reached. This research highlights potential opportunities in breeding and soil management to improve rice production. With rice management shifts to reduced irrigation (e.g. AWD) and reduced tillage, coupled with paddy to upland rotations in the annual cropping cycle in some regions, combining deep rooting varieties with macropore formation and preservation in the soil structure, could improve yield and decrease resource use concurrently.

Acknowledgements This study was funded by the Commonwealth Scholarship Commission in the UK. We thank all people that contributed to this work. In particular, Luke Harrold, Rong Qu, Yehia Hazzazi, Licida Maria Giuliani and Istiaq Ahmed with their stimulating discussion during and after setting experiment. We are highly grateful to Annette Raffan, Dr. Stewart J Chalmers and Jaime Buckingham for providing technical support.

Funding Commonwealth Scholarship Commission in the UK.

Availability of data and material Data files and images are available on request to the corresponding author.

Code availability Not applicable.

\section{Declarations}

Conflict of interest The authors declare that the research was conducted in the absence of any personal, commercial or financial relationships that could have appeared as a potential conflict of interest.

Open Access This article is licensed under a Creative Commons Attribution 4.0 International License, which permits use, sharing, adaptation, distribution and reproduction in any medium or format, as long as you give appropriate credit to the original author(s) and the source, provide a link to the Creative Commons licence, and indicate if changes were made. The images or other third party material in this article are included in the article's Creative Commons licence, unless indicated otherwise in a credit line to the material. If material is not included in the article's Creative Commons licence and your intended use is not permitted by statutory regulation or exceeds the permitted use, you will need to obtain permission directly from the copyright holder. To view a copy of this licence, visit http://creativecommons.org/licenses/by/4.0/.

\section{References}

Araki H, Iijima M (2001) Deep rooting in winter wheat: Rooting nodes of deep roots in two cultivars with deep and shallow root systems. Plant Prod Sci 4:215-219. https:// doi.org/10.1626/pps.4.215

Athmann M, Kautz T, Pude R, Köpke U (2013) Root growth in biopores-evaluation with in situ endoscopy. Plant Soil 371:179-190. https://doi.org/10.1007/s11104-013-1673-5

Atkinson JA, Pound MP, Bennett MJ, Wells DM (2019) Uncovering the hidden half of plants using new advances in root phenotyping. Curr Opin Biotechnol 55:1-8

Atkinson JA, Hawkesford MJ, Whalley WR et al (2020) Soil strength influences wheat root interactions with soil macropores. Plant Cell Environ 43:235-245. https://doi. org/10.1111/pce.13659

Bauke SL, von Sperber C, Siebers N et al (2016) Biopore effects on phosphorus biogeochemistry in subsoils. Soil Biol Biochem 111:157-165. https://doi.org/10.1016/j. soilbio.2017.04.012

Bengough AG, McKenzie BM, Hallett PD, Valentine TA (2011) Root elongation, water stress, and mechanical impedance: a review of limiting stresses and beneficial root tip traits. J Exp Bot 62:59-68. https://doi.org/10. 1093/jxb/erq350

Bottinelli N, Zhou H, Boivin P et al (2016) Macropores generated during shrinkage in two paddy soils using X-ray micro-computed tomography. Geoderma 265:78-86. https://doi.org/10.1016/j.geoderma.2015.11.011

Bouman BAM (2001) Water-efficient management strategies in rice production. Internat Rice Res Notes 16:17-22

Bouman BAM, Tuong TP (2001) Field water management to save water and increase its productivity in irrigated lowland rice. Agric Water Manag 49:11-30. https://doi.org/ 10.1016/S0378-3774(00)00128-1

Bouman BAM, Lampayan RM, Tuong TP (2007) Water Management in Irrigated Rice: Coping with Water Scarcity. International Rice Research Institute, Los Baños, p 54

British Standards Istitute (1990) Soils for civil engineering purposes -Part 2: Classification Tests. 3BSI, London

Chaki AK, Gaydon DS, Dalal RC et al (2021) Puddled and zero-till unpuddled transplanted rice are each best suited to different environments - An example from two diverse locations in the Eastern Gangetic Plains of Bangladesh. F Crop Res 262:108031. https://doi.org/10.1016/j.fcr.2020. 108031

Chen G, Weil RR, Hill RL (2014) Effects of compaction and cover crops on soil least limiting water range and air permeability. Soil Tillage Res 136:61-69. https://doi.org/10. 1016/j.still.2013.09.004

Coats B (2003) Global rice production. In: Smith CW, Dilday RH (eds) Rice origin, history, technology and production. Wiley, Hoboken

Coelho Filho MA, Colebrook EH, Lloyd DPA et al (2013) The involvement of gibberellin signalling in the effect of soil resistance to root penetration on leaf elongation and tiller number in wheat. Plant Soil 371:81-94. https://doi.org/10. 1007/s11104-013-1662-8 
Colombi T, Walter A (2017) Genetic diversity under soil compaction in wheat: root number as a promising trait for early plant vigor. Front Plant Sci 8:420. https://doi.org/10. 3389/fpls.2017.00420

Colombi T, Braun S, Keller T, Walter A (2017) Artificial macropores attract crop roots and enhance plant productivity on compacted soils. Sci Total Environ 574:12831293. https://doi.org/10.1016/j.scitotenv.2016.07.194

Dexter AR (1986) Model experiments on the behaviour of roots at the interface between a tilled seed-bed and a compacted sub-soil: II. Entry of pea and wheat roots into subsoil cracks on JSTOR. Plant Soil 95:135-147

Don A, Steinberg B, Schöning I et al (2008) Organic carbon sequestration in earthworm burrows. Soil Biol Biochem 40:1803-1812. https://doi.org/10.1016/j.soilbio.2008.03. 003

Fang S, Clark RT, Zheng Y et al (2013) Genotypic recognition and spatial responses by rice roots. Proc Natl Acad Sci U S A 110:2670-2675. https://doi.org/10.1073/pnas. 1222821110

Fang H, Zhou H, Norton GJ et al (2018) Interaction between contrasting rice genotypes and soil physical conditions induced by hydraulic stresses typical of alternate wetting and drying irrigation of soil. Plant Soil 430:233243. https://doi.org/10.1007/s11104-018-3715-5

Gaiser T, Perkons U, Küpper PM et al (2013) Modeling biopore effects on root growth and biomass production on soils with pronounced sub-soil clay accumulation. Ecol Modell. https://doi.org/10.1016/j.ecolmodel.2013. 02.016

Godfray HCJ, Beddington JR, Crute IR et al (2010) Food security: The challenge of feeding 9 billion people. Science (80-. ) 327:812-818

Grzesiak S, Grzesiak MT, Hura T et al (2013) Changes in root system structure, leaf water potential and gas exchange of maize and triticale seedlings affected by soil compaction. Environ Exp Bot 88:2-10. https://doi.org/10.1016/j.envex pbot.2012.01.010

Hamza MA, Al-Adawi SS, Al-Hinai KA (2011) Effect of combined soil water and external load on soil compaction. Soil Res 49:135. https://doi.org/10.1071/SR09144

Hasegawa S, Thangaraj M, O'Toole JC (1985) Root behavior: field and laboratory studies for rice and non-rice crops. In: Soil physics and rice. International Rice Research Institute, Manila, pp 383-396

Hirth JR, Mckenzie BM, Tisdall JM (2005) Ability of seedling roots of Lolium perenne L. to penetrate soil from artificial biopores is modified by soil bulk density, biopore angle and biopore relief. Plant Soil 272:327-336. https://doi. org/10.1007/s11104-004-5764-1

Horn R, Smucker A (2005) Structure formation and its consequences for gas and water transport in unsaturated arable and forest soils. Soil Tillage Res 82:5-14. https://doi.org/ 10.1016/j.still.2005.01.002

Ishaq M, Ibrahim M, Lal R (2003) Persistence of subsoil compaction effects on soil properties and growth of wheat and cotton in Pakistan. Exp Agric 39:341-348. https://doi.org/ 10.1017/S0014479703001340

Ishfaq M, Farooq M, Zulfiqar U et al (2020) Alternate wetting and drying: a water-saving and ecofriendly rice production system. Agric Water Manag 241:106363. https://doi.org/ 10.1016/j.agwat.2020.106363

Kautz T (2015) Research on subsoil biopores and their functions in organically managed soils: a review. Renew Agric Food Syst 30:318-327

Kautz T, Amelung W, Ewert F et al (2013) Nutrient acquisition from arable subsoils in temperate climates: a review. Soil Biol Biochem 57:1003-1022

Kautz T, Lüsebrink M, Pätzold S et al (2014) Contribution of anecic earthworms to biopore formation during cultivation of perennial ley crops. Pedobiologia (Jena). https:// doi.org/10.1016/j.pedobi.2013.09.008

Kopke U, Athmann M, Han E, Kautz T (2015) Optimising cropping techniques for nutrient and environmental management in organic agriculture. Sustain Agric Res. https:// doi.org/10.5539/sar.v4n3p15

Landl M, Huber K, Schnepf A, Vanderborght J (2016) A new model for root growth in soil with macropores. Plant Soil. https://doi.org/10.1007/s11104-016-3144-2

Li CK (1992) Paddy soils of China Beijing China. Sci Press, Beijing, pp 156-162

Loades KW, Bengough AG, Bransby MF, Hallett PD (2010) Planting density influence on fibrous root reinforcement of soils. Ecol Eng 36:276-284. https://doi.org/10.1016/j. ecoleng.2009.02.005

Lynch JP, Wojciechowski T (2015) Opportunities and challenges in the subsoil: Pathways to deeper rooted crops. J Exp Bot 66:2199-2210. https://doi.org/10.1093/jxb/ eru508

McDonald AJ, Riha SJ, Duxbury JM et al (2006) Soil physical responses to novel rice cultural practices in the ricewheat system: comparative evidence from a swelling soil in Nepal. Soil Tillage Res 86:163-175. https://doi.org/10. 1016/j.still.2005.02.005

McKenzie BM, Bengough AG, Hallett PD et al (2009) Deep rooting and drought screening of cereal crops: a novel field-based method and its application. F Crop Res. https://doi.org/10.1016/j.fcr.2009.02.012

McNally KL, Childs KL, Bohnert R et al (2009) Genomewide SNP variation reveals relationships among landraces and modern varieties of rice. Proc Natl Acad Sci U S A 106:12273-12278. https://doi.org/10.1073/pnas.09009 92106

Munasinghe M, Price AH (2016) Genetic and root phenotype diversity in Sri Lankan rice landraces may be related to drought resistance. Rice 9:1-13. https://doi.org/10.1186/ s12284-016-0092-7

Passioura JB (1991) Soil structure and plant growth. Aust J Soil Res 29:717-728

Passioura JB (2002) Soil conditions and plant growth. Plant Cell Environ 25:311-318. https://doi.org/10.1046/j.00168025.2001.00802.X

Pfeifer J, Kirchgessner N, Walter A (2014) Artificial pores attract barley roots and can reduce artifacts of pot experiments. J Plant Nutr Soil Sci 177:903-913. https://doi.org/ 10.1002/jpln.201400142

Raza W, Yousaf S, Niaz A, ... MR (2005) Subsoil compaction effects on soil properties, nutrient uptake and yield of maize fodder (Zea mays L.). Pak J Bot 37:933-940

Ringrose-Voase AJ (1996) Measurement of soil macropore geometry by image analysis of sections through 
impregnated soil. Plant Soil 183:27-47. https://doi.org/10. 1007/BF02185563

Rosolem CA, Foloni JSS, Tiritan CS (2002) Root growth and nutrient accumulation in cover crops as affected by soil compaction. Soil Tillage Res. https://doi.org/10.1016/ S0167-1987(01)00286-0

Samson BK, Hasan M, Wade LJ (2002) Penetration of hardpans by rice lines in the rainfed lowlands. Field Crop Res 76:175-188. https://doi.org/10.1016/S0378-4290(02) 00038-2

Schneider F, Don A, Hennings I et al (2017) The effect of deep tillage on crop yield - What do we really know? Soil Tillage Res 174:193-204

Shrestha R, Al-Shugeairy Z, Al-Ogaidi F et al (2014) Comparing simple root phenotyping methods on a core set of rice genotypes. Plant Biol 16:632-642. https://doi.org/10. 1111/plb.12096

Singh SP, Jain A, Anantha MS et al (2017) Depth of soil compaction predominantly affects rice yield reduction by reproductive-stage drought at varietal screening sites in Bangladesh, India, and Nepal. Plant Soil 417:377-392. https://doi.org/10.1007/s11104-017-3265-2

Stirzaker RJ, Passioura JB, Sutton BG, Collis-Georg N (1993) Soil management for irrigated vegetable production. II* Possible causes for slow vegetative growth of lettuce associated with zero tillage. Aust J Agric Res 44:831-844. https://doi.org/10.1071/AR9930831

Stirzaker RJ, Passioura JB, Wilms Y (1996) Soil structure and plant growth: impact of bulk density and biopores. Plant Soil. https://doi.org/10.1007/BF02257571

Strachan G, Capel S, Maciel H et al (2002) Application of cellular and immunological biosensor techniques to assess herbicide toxicity in soils. Eur J Soil Sci 53:37-44. https:// doi.org/10.1046/j.1365-2389.2002.00421.x
Team RC (2020a) A language and environment for statistical computing. R Foundation for Statistical Computing, Vienna. https://www.R-project.org/

Team Rs (2020b) RStudio: Integrated Development Environment for R. RStudio, PBC, Boston. http://www.rstudio. $\mathrm{com} /$

White RG, Kirkegaard JA (2010) The distribution and abundance of wheat roots in a dense, structured subsoil - Implications for water uptake. Plant Cell Environ 33:133-148. https://doi.org/10.1111/j.1365-3040.2009.02059.x

Yoshida S, Hallett PD (2008) Impact of hydraulic suction history on crack growth mechanics in soil. Water Resour Res 44:01. https://doi.org/10.1029/2007WR006055

Zhang ZB, Zhou H, Zhao QG et al (2014) Characteristics of cracks in two paddy soils and their impacts on preferential flow. Geoderma 228-229:114-121. https://doi.org/10. 1016/j.geoderma.2013.07.026

Zhao K, Tung CW, Eizenga GC et al (2011) Genome-wide association mapping reveals a rich genetic architecture of complex traits in Oryza sativa. Nat Commun 2:1-10. https://doi.org/10.1038/ncomms1467

Zhou H, Whalley WR, Hawkesford MJ et al (2021) The interaction between wheat roots and soil pores in structured field soil. J Exp Bot 72:747-756. https://doi.org/10.1093/ jxb/eraa475

Publisher's note Springer Nature remains neutral with regard to jurisdictional claims in published maps and institutional affiliations. 